\title{
Energy expenditure in infants with congenital heart disease, including a meta-analysis
}

Citation for published version (APA):

van der Kuip, M., Hoos, M. B., Forget, P., Westerterp, K. R., Gemke, R. J., \& de Meer, K. (2003). Energy expenditure in infants with congenital heart disease, including a meta-analysis. Acta Paediatrica, 92(8), 921-927. https://doi.org/10.1080/08035250310003569

Document status and date:

Published: 01/01/2003

DOI:

10.1080/08035250310003569

Document Version:

Publisher's PDF, also known as Version of record

Document license:

Taverne

\section{Please check the document version of this publication:}

- A submitted manuscript is the version of the article upon submission and before peer-review. There can be important differences between the submitted version and the official published version of record.

People interested in the research are advised to contact the author for the final version of the publication, or visit the DOI to the publisher's website.

- The final author version and the galley proof are versions of the publication after peer review.

- The final published version features the final layout of the paper including the volume, issue and page numbers.

Link to publication

\footnotetext{
General rights rights.

- You may freely distribute the URL identifying the publication in the public portal. please follow below link for the End User Agreement:

www.umlib.nl/taverne-license

Take down policy

If you believe that this document breaches copyright please contact us at:

repository@maastrichtuniversity.nl

providing details and we will investigate your claim.
}

Copyright and moral rights for the publications made accessible in the public portal are retained by the authors and/or other copyright owners and it is a condition of accessing publications that users recognise and abide by the legal requirements associated with these

- Users may download and print one copy of any publication from the public portal for the purpose of private study or research.

- You may not further distribute the material or use it for any profit-making activity or commercial gain

If the publication is distributed under the terms of Article $25 \mathrm{fa}$ of the Dutch Copyright Act, indicated by the "Taverne" license above, 


\title{
Energy expenditure in infants with congenital heart disease, including a meta-analysis
}

\author{
M van der Kuip ${ }^{1}$, MB Hoos ${ }^{3}$, PP Forget ${ }^{3}$, KR Westerterp ${ }^{4}$, RJBJ Gemke ${ }^{1}$ and K de Meer ${ }^{1,2}$ \\ Department of Paediatrics ${ }^{1}$, VU University Medical Centre, Amsterdam, The Netherlands; Department of Paediatric Gastroenterology ${ }^{2}$, \\ Wilhelmina Kinderziekenhuis/University Medical Centre Utrecht, Utrecht, The Netherlands; Department of Paediatrics ${ }^{3}$, University \\ Hospital Maastricht, Maastricht, The Netherlands; Department of Human Biology ${ }^{4}$, Maastricht University, Maastricht, The Netherlands
}

van der Kuip M, Hoos MB, Forget PP, Westerterp KR, Gemke RJBJ, de Meer K. Energy expenditure in infants with congenital heart disease, including a meta-analysis. Acta Pædiatr 2003; 92: 921-927. Stockholm. ISSN 0803-5253

\begin{abstract}
Aim: To assess energy requirements and body composition in preoperative children with congenital heart disease (CHD). Methods: In 11 infants with CHD (2-8 mo), total daily energy expenditure (TDEE) and total body water (TBW) were measured with doubly labelled water and compared with historic data from healthy controls. Within the patient group, energy expenditure of infants with versus those without congestive heart failure was compared. Subsequently, the data were pooled with literature data in meta-analyses. Results: CHD patients showed increased TBW (mean \pm SD $66 \pm 3$ vs $58 \pm 5 \%$ of body weight, $p<0.05)$ and energy expenditure $(381 \pm 42$ vs $\left.298 \pm 36 \mathrm{~kJ} \mathrm{~kg}^{-1} \mathrm{~d}^{-1}, p<0.001\right)$. Meta-analyses showed that CHD infants have $35 \%$ increased TDEE (376 vs $\left.278 \mathrm{~kJ} \mathrm{~kg}^{-1} \mathrm{~d}^{-1}, p<0.00001\right)$ and $7 \%$ higher TBW $(p<0.0001)$. Coexistent congestive heart failure (treated with diuretics) had no influence on TDEE (mean difference $14 \mathrm{~kJ} \mathrm{~kg}^{-1} \mathrm{~d}^{-1}$, not significant). In patients with heart failure and growth retardation, an energy balance study showed an average $12 \%$ loss of initially ingested energy due to vomiting, increased TDEE and low faecal energy loss, resulting in low energy available for growth, compared with controls $\left(42 \pm 30\right.$ vs $\left.96 \pm 61 \mathrm{~kJ} \mathrm{~kg}^{-1} \mathrm{~d}^{-1}, p<0.05\right)$.

Conclusion: Many infants with CHD require substantially higher energy intake (at least $100 \mathrm{~kJ} \mathrm{~kg}^{-1} \mathrm{~d}^{-1}$ extra) owing to increased TDEE, which is not explained by a higher percentage of body water. Coexistent heart failure does not appear to have an additional influence on TDEE. In infants with CHD and growth failure factors other than elevated TDEE, including vomiting, may explain the disturbed energy balance.
\end{abstract}

Key words: Congenital heart disease, doubly labelled water, energy expenditure, meta-analysis

RJBJ Gemke, Department of Paediatrics, VU University Medical Centre, PO Box 7057, NL-1007 MB Amsterdam, The Netherlands (Tel. +31 20444 2413, fax. +31 20444 3045, e-mail. rjbj.gemke@vumc.nl)

Growth retardation is a recognized feature in infants with congenital heart disease (CHD). Apart from elevated energy expenditure, reduction of food intake might interfere with normal requirements for growth. Elevated energy expenditure in these patients is generally attributed to their abnormal haemodynamics, but explanations such as altered body composition are also possible. In one study, faecal energy excretion was not shown to be elevated in infants with CHD (1).

The quantification of increased energy expenditure in infants with CHD is important for the nutritional management of this patient group. To assess resting energy expenditure in children with $\mathrm{CHD}$, several gasexchange studies were performed (2-7). Currently, the doubly labelled water (DLW) technique is considered the gold standard for the measurement of total daily energy expenditure (TDEE), which includes energy expended in physical activity. It is suitable for freeliving subjects and measures TDEE over a period of days, but is costly and requires specialized laboratory equipment. Several studies using this technique in infants with CHD have been published during the past decade (8-13). Although TDEE was shown to be elevated in most of these studies (8-13), each study included a small number of patients with a variety of clinical symptoms and anatomical abnormalities. TDEE has not been studied extensively in infants with CHD and congestive heart failure (CHF) who have developed growth failure, and these patients require special attention owing to their precarious fluid and energy balance. The limitations in accuracy, patient definition and lack of data in this subgroup limit the conclusions with respect to the energy requirements for specific patient groups with CHD.

The present study assessed energy requirements and body composition by the measurement of TDEE and total body water (TBW) with the DLW technique in preoperative CHD infants and compared them with 
Table 1. Characteristics of patients and controls.

\begin{tabular}{|c|c|c|c|c|c|c|c|c|c|c|c|}
\hline No. & Diagnosis & CHF & $\begin{array}{l}\text { Growth } \\
\text { retarded }\end{array}$ & Gender & $\begin{array}{l}\text { Weight } \\
(\mathrm{kg})\end{array}$ & $\begin{array}{l}\text { Length } \\
(\mathrm{cm})\end{array}$ & $\begin{array}{l}\text { Age } \\
(\mathrm{mo})\end{array}$ & $\begin{array}{c}\text { Weight } \\
\text { (percentile) }\end{array}$ & $\begin{array}{c}\text { Length } \\
\text { (percentile) }\end{array}$ & $\begin{array}{l}\text { TBW } \\
(\%)\end{array}$ & $\begin{array}{c}\mathrm{TDEE} \\
\left(\mathrm{kJ} \mathrm{kg}^{-1} \mathrm{~d}^{-1}\right)\end{array}$ \\
\hline 1 & CoAo, $\mathrm{VSD}^{\mathrm{a}}$ & + & + & $\mathrm{F}$ & 3.04 & 51.0 & 2.3 & $3.1(<\mathrm{p} 3)$ & $55.30(\mathrm{p} 15)$ & 63.6 & 401 \\
\hline 2 & DS, ASD, AVSD, DORV, PAS & + & + & $\mathrm{F}$ & 3.72 & 52.0 & 5.8 & $4.9(<\mathrm{p} 3)$ & $61.40(\mathrm{p} 3)$ & 66.9 & 373 \\
\hline 3 & AVSD $^{\mathrm{a}}$ & + & + & M & 3.00 & 50.0 & 4.3 & $4.9(<\mathrm{p} 3)$ & $63.50(\mathrm{p} 25)$ & 68.8 & 410 \\
\hline 4 & $\mathrm{AVSD}^{\mathrm{a}}$ & + & + & $\mathrm{F}$ & 3.52 & 47.5 & 3.4 & $3.8(<\mathrm{p} 3)$ & $56.80(\mathrm{p} 5)$ & 64.7 & 411 \\
\hline 5 & AVSD, PAS ${ }^{\mathrm{a}}$ & + & + & M & 3.69 & 52.0 & 7.0 & $6.0(<\mathrm{p} 3)$ & $71.00(\mathrm{p} 50)$ & 62.3 & 355 \\
\hline 6 & VSD & + & - & $\mathrm{F}$ & 3.22 & 49.5 & 5.2 & $6.4(\mathrm{p} 25)$ & $63.0(\mathrm{p} 25)$ & 61.1 & 322 \\
\hline 7 & VSD & - & - & $\mathrm{F}$ & 4.00 & 50.0 & 5.1 & $6.3(\mathrm{p} 25)$ & $57.5(<\mathrm{p} 3)$ & 67.5 & 398 \\
\hline 8 & VSD, ASD & - & - & $\mathrm{F}$ & 2.76 & 44.0 & 1.9 & $4.4(\mathrm{p} 25)$ & $56.8(\mathrm{p} 55)$ & 71.7 & 408 \\
\hline 9 & VSD, ASD & - & - & $\mathrm{F}$ & 3.53 & 51.0 & 7.5 & $7.0(\mathrm{p} 15)$ & 69.7 (p65) & 64.1 & 372 \\
\hline 10 & VSD & - & - & M & 2.69 & 47.0 & 4.0 & $6.9(\mathrm{p} 50)$ & $59.3(\mathrm{p} 3)$ & 66.6 & 299 \\
\hline 11 & DS, VSD & - & + & M & 3.03 & 48.0 & 6.3 & $5.3(<\mathrm{p} 3)$ & $63.0(<\mathrm{p} 3)$ & 68.1 & 442 \\
\hline \multicolumn{2}{|c|}{ CHD } & \multirow{2}{*}{\multicolumn{2}{|c|}{$\begin{array}{l}(\text { mean } \pm \mathrm{SD}) \\
(\text { mean }\end{array}$}} & $4 \mathrm{M} / 7 \mathrm{~F}$ & $3.29 \pm 43$ & $49.3 \pm 2.9$ & $4.8 \pm 1.8$ & $5.6 \pm 1.2$ & $61.6 \pm 5.2$ & $66 \pm 3$ & $381 \pm 42$ \\
\hline Con & trols & & & $15 \mathrm{M} / 8 \mathrm{~F}$ & $3.56 \pm 47$ & $49.0 \pm 0.5$ & $4.3 \pm 2.5$ & $6.9 \pm 1.3^{*}$ & $64.4 \pm 5.6$ & $58 \pm 5$ & $298 \pm 36$ \\
\hline
\end{tabular}

${ }^{\text {a }}$ Participated in the energy balance study.

CHF: congestive heart failure; TBW: total body water; TDEE: total daily energy expenditure; CoAo: coarctation of the aorta; VSD: ventricular septal defect; DS: Down's syndrome; ASD: atrial septal defect; AVSD: atrioventricular septal defect; DORV: double outlet right ventricle; PAS: pulmonary artery stenosis; CHD: congenital heart disease; F: female; M: male.

$* p<0.01$.

healthy, age-matched controls. In the patient group, energy expenditure of infants with CHF and those without CHF was compared. Furthermore, in a subgroup of $\mathrm{CHD}$ patients with $\mathrm{CHF}$ and growth retardation, the energy balance was assessed by calculated and measured energy intake, including measured faecal energy excretion. It was hypothesized that these children have less energy for growth, owing to a raised TDEE, impaired intake and possibly raised faecal energy excretion. In addition to the clinical studies, and to strengthen the conclusions from this study and other small patient groups published in the literature, data of TDEE and TBW as measured with the DLW technique in CHD infants, and in those with CHF versus those without $\mathrm{CHF}$, were pooled and analysed in metaanalyses.

\section{Material and methods}

\section{Study design}

From two university hospitals in The Netherlands (University Medical Centre, Utrecht, and University Hospital, Maastricht), 11 patients with CHD characterized by left-to-right shunt were enrolled for a prospective observational study. Measurements involved the assessment of TDEE and TBW using the DLW technique. In a subgroup of five patients, energy intake, energy ingestion and faecal energy losses were also measured during a 3-5 d period. For comparison, data from a historic group of 23 healthy, age-matched controls were used. Subsequently, a meta-analysis was performed to enhance the power of the conclusions in this small group of patients.

The institutional review board in each of the two institutes approved the study. Informed consent was obtained from the parents of all subjects.

\section{Subjects}

Patients with congenital heart disease. Infants with acquired heart disease, major congenital anomalies outside the circulatory tract, chromosomal abnormalities other than trisomy 21 , unstable clinical or social condition, or severe hypoxaemia (saturation $<70 \%$ ), and those in need of heart surgery within the next month, were excluded. The diagnosis of CHD with a large left-to-right shunt was confirmed by echocardiography and/or heart catheterization. Concomitant CHF was present when at least three of the following criteria were found: resting sinus tachycardia of $>150$ beats $\min ^{-1}$, tachypnoea of $>60$ breaths $\min ^{-1}$, chest retractions without pulmonary cause, hepatomegaly, fluid restriction of $<130 \mathrm{ml} \mathrm{kg}^{-1} \mathrm{~d}^{-1}$ and/or diuretics, left atrium/aorta ratio of $>1.3$, and a heart/thorax ratio on chest X-ray of $>0.6$. Growth retardation was defined as underweight, i.e. weight for age $<10$ th percentile or weight for age $<25$ th percentile in combination with a weight gain from birth until enrolment of $<100 \mathrm{~g} \mathrm{wk}^{-1}$.

Thus, 11 patients $(4 \mathrm{M}, 7 \mathrm{~F})$, aged between 2 and 8 mo, were enrolled. Table 1 shows the patients' characteristics. Six patients met the criteria of CHF; they were treated with digoxin $\left(0.01 \mathrm{mg} \mathrm{kg}^{-1} \mathrm{~d}^{-1}\right)$, furosemide $\left(3 \mathrm{mg} \mathrm{kg}^{-1} \mathrm{~d}^{-1}\right)$ and spironolactone $\left(3 \mathrm{mg} \mathrm{kg}^{-1} \mathrm{~d}^{-1}\right)$. Of the five patients without CHF, one was treated with furosemide and spironolactone, and one with hydrochlorothiazide and triamterene. Seven patients were growth retarded according to the study criteria; the five infants with growth retardation and CHF entered the energy balance study. The patients in this group were monitored with the help of a research nurse, and received high-energy infant formula $\left(418 \mathrm{~kJ}^{\left.100 \mathrm{ml}^{-1}\right)}\right.$ with an intended energy intake of $502 \mathrm{~kJ} \mathrm{~kg}^{-1} \mathrm{~d}^{-1}$.

Control infants. Data on TDEE, TBW and energy intake 
from 46 healthy Dutch infants were used. They had been included in a study of longitudinal TDEE and body composition, conducted in the area of Rotterdam between 1992 and 1995, as reported previously (14). That study used the same clinical protocol and laboratory methods for the DLW technique as was used in the present study. For the control group, only data on the 23 formula-fed infants were used. The control group consisted of Caucasian, healthy infants, born at term, after an uncomplicated pregnancy, with a birthweight $>2500 \mathrm{~g}$. For both patient and control studies, measurements of enrichment in hydrogen and oxygen in urine samples were performed in the same laboratory (by KR Westerterp), using the same equipment and standard operating procedures.

All patients and control infants were fed exclusively with infant formula; they received no breast milk or solids.

\section{Anthropometry}

Weight and crown-heel length were measured in the hospital using standardized equipment, and standard deviation scores (SDS) for weight, height and body mass index (BMI) were calculated, using data from the fourth national survey on growth in The Netherlands (15).

\section{Doubly labelled water technique}

TDEE and TBW were measured by the DLW technique, as described previously (16). A urine sample was taken for background enrichment of body water. Subsequently, the infants received a weighted dose of ${ }^{2} \mathrm{H}_{2}{ }^{18} \mathrm{O}$ ( $3 \mathrm{~g} \mathrm{~kg}^{-1}$ body weight) through a nasogastric tube or after dissolving the isotopes in the formula feed (bottles were thoroughly rinsed). Four hours later, a second urine sample was collected. Subsequently, on days 1,3 and 5 , the research nurse collected urine samples at home. The urine samples were obtained with a plastic collector bag or with cotton dental wool placed in a disposable diaper.

After equilibration (4h), TBW was estimated from the ${ }^{18} \mathrm{O}$ and ${ }^{2} \mathrm{H}$ dilution spaces. Water turnover was calculated from the ${ }^{2} \mathrm{H}$ elimination rate. Because ${ }^{2} \mathrm{H}$ is solely eliminated as ${ }^{2} \mathrm{H}_{2} \mathrm{O}$ (allowing calculation of water turnover), whereas ${ }^{18} \mathrm{O}$ is eliminated as both $\mathrm{H}_{2}{ }^{18} \mathrm{O}$ and $\mathrm{C}^{18} \mathrm{O}_{2}, \mathrm{CO}_{2}$ production can be calculated from the difference in isotope decay of ${ }^{18} \mathrm{O}$ and ${ }^{2} \mathrm{H}$ during the measuring period. From $\mathrm{CO}_{2}$ production, TDEE was calculated with Weir's equation (17), without correction for nitrogen excretion, assuming a respiratory quotient of 0.89 , which was derived from the proportional amounts of macronutrients in the formula feed.

\section{Energy balance study}

A $72 \mathrm{~h}$ energy balance study was conducted in five patients with CHF and growth retardation. During the TDEE measurements, the actual food intake was calculated from water turnover (deuterium turnover) multiplied by the energy density of the formula feed (16). All feeds were prepared and checked for energy content by the manufacturer and were delivered in closed bottles (content per $100 \mathrm{ml}: 10.4 \mathrm{~g}$ carbohydrate, $2.6 \mathrm{~g}$ protein, $5.4 \mathrm{~g}$ triglycerides, i.e. $418 \mathrm{~kJ}$ ). The research nurse collected all stools at home. Faeces was collected in the diapers with fat-free paper, which retained the faeces but not the urine. Faecal specimens were transferred into plastic containers kept at $4^{\circ} \mathrm{C}$ until the end of the balance study, and then frozen at $-20^{\circ} \mathrm{C}$ until analysis. Faecal energy content was measured by bomb calorimetry (C-400; IKA Kalorimeter, Janke, Germany) and corrected for faeces retained in the collection paper, as described previously (18). Parents documented vomiting and the amount of administered formula feed in specially designed diaries; the research nurse was in close contact with the parents during that period. Net energy for growth was calculated from ingested energy minus TDEE and faecal energy loss.

\section{Literature review of studies on total daily energy expenditure in infants with congenital heart disease}

A computerized search for relevant articles was performed on MEDLINE (Pubmed), using the following text, title, abstract words or MESH terms: congenital heart disease, congestive heart failure, energy expenditure, doubly labelled water, and "heart defects, congenital/metabolism" with the limits: all child: $0-18 \mathrm{y}$. In addition, reference lists of reviews and relevant original articles and abstracts of recent scientific meetings were searched. Studies using the DLW technique were included if patients were between 2 and $8 \mathrm{mo}$ of age and preoperative, and if a control group of healthy children was included. These criteria enabled comparison of the data with the present study and most other studies. The studies were analysed for TDEE $\mathrm{kg}^{-1} \mathrm{~d}^{-1}$ and TBW (as percentage of body weight). Within the aggregated patient group, an analysis was conducted for TDEE between CHD infants with and without $\mathrm{CHF}$.

The search strategy resulted in 12 citations from Pubmed and one abstract from the annual meeting of the Pediatric Academic Societies in May 2002. Of these 13 citations, 6 original articles, 1 abstract and 1 review article described the DLW technique in children with CHD $(8-13,19,20)$. The study by Mitchell et al. (18 patients) was excluded because the mean age of the population was $15.6 \mathrm{mo}$ (range 4-33 mo) (9). Leitch et al. published two original articles, using DLW. One of them was excluded because it measured TDEE after surgical repair (12). In the other study, serial measurements in children with CHD at $2 \mathrm{wk}$ and 3 mo were performed (13). Data from the first measurement were excluded owing to a mean age of 2 wk. Barton et al. (8) compared their data with a dataset from Davies et al. (21). Since they do not mention TBW of the reference group of Davies et al., this study was excluded from the 
Table 2. Energy balance in expenditure in infants with congenital heart disease (CHD) and growth retardation versus healthy controls.

\begin{tabular}{lccr}
\hline & CHD infants $(n=5)$ & Controls $(n=23)$ & Mean difference $(95 \%$ CI $)$ \\
\hline Age (mo) & $4.6 \pm 1.9$ & $4.3 \pm 2.5$ & - \\
Energy offered $^{\mathrm{a}}$ & 502 & na & - \\
Energy ingested $^{\mathrm{a}}$ & $441 \pm 40$ & $403 \pm 56$ & na \\
Energy loss & $9 \pm 4$ & $298 \pm 36$ & - \\
TDEE & $390 \pm 25$ & $97 \pm 60^{\mathrm{b}}$ & $91(61$ to 121$)$ \\
Energy for growth & $42 \pm 30$ & $-55(-19$ to -92$)$ \\
\hline
\end{tabular}

Data are shown as mean $\pm \mathrm{SD}$; energy data in $\mathrm{kJ} \mathrm{kg}^{-1}$ body weight $\mathrm{d}^{-1}$.

${ }^{\text {a }}$ From water turnover.

${ }^{\mathrm{b}}$ Faecal energy loss in control infants assumed at $9 \mathrm{~kJ} \mathrm{~kg}^{-1} \mathrm{~d}^{-1}$.

na: not assessed; TDEE: total daily energy expenditure; $95 \%$ CI: $95 \%$ confidence interval.

comparison for TBW. Thus, 5 studies met the inclusion criteria $(8,10,11,19,20)$, in which a total of 54 infants with CHD and 101 healthy controls was described. Furthermore, TDEE in CHD infants with or without $\mathrm{CHF}$ was compared. For this analysis two studies were excluded $(13,19)$. In one, none of the infants had CHF (13), while the other did not indicate those children with or without CHF (19).

\section{Statistical analysis}

Values are reported as mean \pm SD. Statistical analysis was performed using SPSS for Windows (SPSS Inc., Chicago). Statistical comparisons were made with Student's $t$-tests. Pearson correlation analyses were conducted for the comparison of TDEE and SDS for weight. Statistical analysis for the meta-analysis was performed with Review Manager 4.1 (Cochrane Collaboration), which enables the calculation of a pooled effect size of weighted mean differences of the included studies. The weight (\%) is based on study size and variation of the data (SD). Heterogeneity of the combined studies was assessed with this package and considered significant if $p<0.1$. Other statistical differences were considered significant if $p<0.05$ (two-tailed).

\section{Results}

\section{Anthropometry}

Weight and length are shown in Table 1. Infants with CHD had significantly decreased SDS for weight $[-1.60,95 \%$ confidence interval $(95 \% \mathrm{CI})-2.23$ to $-0.93]$, length $(-1.01,95 \% \mathrm{CI}-1.75$ to -0.38$)$ and BMI $(-2.1,95 \%$ CI -3.27 to -0.84$)$ for age (15). Weight at enrolment was also significantly different between patients and controls (Table 1, mean difference: $-0.95 \mathrm{~kg}, 95 \% \mathrm{CI}-1.84$ to $-0.07, p<0.05$ ), but length was not.

\section{Total daily energy expenditure and total body water}

All subjects gained weight during the period when the DLW method was conducted. The mean TDEE of the CHD patients was significantly elevated compared with the controls (mean $\pm \mathrm{SD} \quad 381 \pm 42$ vs $298 \pm 36$ $\mathrm{kJ} \mathrm{kg}^{-1} \mathrm{~d}^{-1}$; mean difference $83,95 \%$ CI 56 to 114 , $p<0.001)$. The mean percentage of TBW in infants with CHD was significantly increased compared with the control infants (66 $\pm 3 \%$ vs $58 \pm 5 \%$ of body weight (mean difference $8,95 \%$ CI 5 to $11, p<0.001$ ).

TDEE of CHD infants was not different between those with and without $\mathrm{CHF}(384 \pm 53$ vs $379 \pm$ $36 \mathrm{~kJ} \mathrm{~kg}^{-1} \mathrm{~d}^{-1}$; mean difference $-5,95 \% \mathrm{CI}-72$ to 61). TDEE expressed as $\mathrm{kJ} \mathrm{kg}^{-1} \mathrm{~d}^{-1}$ was inversely correlated with SDS for weight in the CHD children (Pearson correlation coefficient $-0.66, p<0.05$ ). TBW showed no difference between patients with CHF and those without CHF.

\section{Energy balance in congenital heart disease infants with congestive heart failure and growth retardation}

Results are shown in Table 2. Each patient in this subgroup had received the feeds $\left(502 \mathrm{~kJ} \mathrm{~kg}^{-1} \mathrm{~d}^{-1}\right)$ as intended, as evidenced from the diary and counting of bottles. From the diaries it was documented that each patient had vomited repeatedly during the observation period. The mean percentage of lost fluid was $12 \%$ (range 5-25\%) of the offered feeds. Calculation from water turnover demonstrated the lower energy ingestion (mean $441 \mathrm{~kJ} \mathrm{~kg}^{-1} \mathrm{~d}^{-1}$, range $377-470$; mean difference compared with received intake $-61 \mathrm{~kJ} \mathrm{~kg}^{-1} \mathrm{~d}^{-1}$, 95\% CI-102 to $-20, p<0.01)$. Energy losses in the stool were low $\left(9 \pm 4 \mathrm{~kJ} \mathrm{~kg}^{-1} \mathrm{~d}^{-1}\right)$. TDEE was significantly elevated in this subgroup compared with the controls, but not significantly different from the other patients with CHD. Energy available for growth in the subgroup of CHD was significantly decreased and less than half the amount available in controls.

\section{Meta-analysis}

Table $3 \mathrm{a}$ and $\mathrm{b}$ show the comparison of TDEE and TBW of CHD infants with healthy controls, respectively. Table $3 \mathrm{c}$ shows the comparison of TDEE within the patient group between those with or without CHF. Significant heterogeneity of the three analyses was excluded ( $p$-values in tables), which enabled the data to be pooled. The overall effect size for TDEE and 
Table 3. Results of meta-analyses

(a) Total daily energy expenditure in infants with congenital heart disease $(n=65)$ versus healthy controls $(n=124)$.

\begin{tabular}{|c|c|c|c|c|c|c|c|c|c|}
\hline \multirow[b]{2}{*}{ Study } & \multirow[b]{2}{*}{ Year } & \multicolumn{2}{|c|}{ Patients } & \multicolumn{2}{|c|}{ Controls } & \multirow{2}{*}{$\begin{array}{l}\text { Weighted mean difference } \\
\text { (95\% CI fixed) }\end{array}$} & \multirow{2}{*}{$\begin{array}{l}\text { Weight } \\
(\%)\end{array}$} & \multicolumn{2}{|c|}{ Weighted mean difference } \\
\hline & & $n$ & Mean \pm SD & $n$ & Mean \pm SD & & & Mean difference & $(95 \% \mathrm{CI})$ \\
\hline Barton et al. (8) & 1995 & 8 & $425 \pm 100$ & 40 & $280 \pm 60$ & $\rightarrow$ & 6.3 & 145 & (73 to 217 ) \\
\hline Leitch et al. (13) & 1998 & 10 & $391 \pm 98$ & 12 & $302 \pm 55$ & $\rightarrow$ & 6.9 & 89 & (21 to 157$)$ \\
\hline Ackerman et al. (10) & 1998 & 8 & $367 \pm 45$ & 10 & $259 \pm 43$ & - & 19.2 & 108 & (67 to 149 ) \\
\hline Farrell et al. $(11)^{\mathrm{a}}$ & 2001 & 10 & $385 \pm 83$ & 13 & $255 \pm 38$ & $\rightarrow$ & 10.5 & 130 & (75 to 185 ) \\
\hline Farrell et al. $(11)^{\mathrm{b}}$ & 2001 & 7 & $322 \pm 71$ & 13 & $255 \pm 38$ & $\rightarrow-$ & 10.1 & 67 & (11 to 124$)$ \\
\hline Leitch et al. (9) & 2002 & 11 & $377 \pm 103$ & 13 & $258 \pm 29$ & $\rightarrow-$ & 8.2 & 118 & (56 to 182 ) \\
\hline Present study & 2002 & 11 & $381 \pm 42$ & 23 & $298 \pm 36$ & + & 38.4 & 83 & (54 to 112 ) \\
\hline \multirow[t]{3}{*}{ Pooled data } & - & 65 & 376 & 124 & 278 & $\diamond$ & 100 & 98 & (80 to 116$)$ \\
\hline & & & & & & $\begin{array}{lllllll}-3001 & -2001 & -160 & 0 & 1006 & 2003 & 3000\end{array}$ & & & \\
\hline & & \multicolumn{8}{|c|}{$\mathrm{kJ} / \mathrm{kg} / \mathrm{day}$} \\
\hline
\end{tabular}

${ }^{\text {a }}$ Group with congestive heart failure; ${ }^{b}$ group without congestive heart failure.

Total daily energy expenditure in $\mathrm{kJ} \mathrm{kg}^{-1} \mathrm{~d}^{-1}$.

95\% CI: $95 \%$ confidence interval.

Test for heterogeneity: $\chi^{2}=5.84, \mathrm{df}=6, p=0.44$; test for overall effect: $z=10.73, p<0.00001$.

(b) Total body water in infants with congenital heart disease $(n=57)$ versus healthy controls $(n=84)$.

\begin{tabular}{|c|c|c|c|c|c|c|c|c|c|}
\hline \multirow[b]{2}{*}{ Study } & \multirow[b]{2}{*}{ Year } & \multicolumn{2}{|c|}{ Patients } & \multicolumn{2}{|c|}{ Controls } & \multirow{2}{*}{$\begin{array}{l}\text { Weighted mean difference } \\
\text { (95\% CI fixed) }\end{array}$} & \multirow{2}{*}{$\begin{array}{l}\text { Weight } \\
(\%)\end{array}$} & \multicolumn{2}{|c|}{ Weighted mean difference } \\
\hline & & $n$ & Mean \pm SD & $n$ & Mean \pm SD & & & Mean difference & $(95 \% \mathrm{CI})$ \\
\hline Leitch et al. (13) & 1998 & 10 & $73.6 \pm 6.6$ & 12 & $71.6 \pm 7.0$ & & 12.0 & 2.0 & $(-3.7$ to 7.7$)$ \\
\hline Ackerman et al. (10) & 1998 & 8 & $69.2 \pm 1.2$ & 10 & $59.7 \pm 6.4$ & $\rightarrow$ & 23.7 & 9.5 & (5.5 to 13.6$)$ \\
\hline Farrell et al. $(11)^{\mathrm{a}}$ & 2001 & 10 & $72.0 \pm 7.0$ & 13 & $60.0 \pm 12.6$ & $\rightarrow$ & 5.9 & 12.0 & (3.9 to 20.1 ) \\
\hline Farrell et al. $(11)^{\mathrm{b}}$ & 2001 & 7 & $64.0 \pm 9.0$ & 13 & $60.0 \pm 12.6$ & 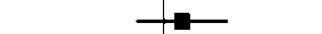 & 4.3 & 4.0 & ( -5.6 to 13.6$)$ \\
\hline Leitch et al. (9) & 2002 & 11 & $65.1 \pm 11.9$ & 13 & $59.6 \pm 5.6$ & $=$ & 6.6 & 5.5 & $(-2.2$ to 13.2$)$ \\
\hline Present study & 2002 & 11 & $65.9 \pm 3.1$ & 23 & $58.2 \pm 5.4$ & + & 47.4 & 7.7 & (4.8 to 10.6$)$ \\
\hline \multirow[t]{3}{*}{ Pooled data } & - & 57 & 67.8 & 84 & 60.4 & $\diamond$ & 100 & 7.4 & (5.4 to 9.4 ) \\
\hline & & & & & & $\begin{array}{lllllll}-30 & -20 & -10 & 0 & 10 & 20 & 30\end{array}$ & & & \\
\hline & & & & & & \% of bodyweight & & & \\
\hline
\end{tabular}

${ }^{\text {a }}$ Group with congestive heart failure; ${ }^{\mathrm{b}}$ group without congestive heart failure.

Total body water in percentage of body weight.

95\% CI: 95\% confidence interval.

Test for heterogeneity: $\chi^{2}=6.49, \mathrm{df}=5, p=0.26$; test for overall effect: $z=7.34, p<0.00001$.

(c) Total daily energy expenditure in infants with congenital heart disease with congestive heart failure (CHF) ( $n=26)$ versus without CHF $(n=18)$.

\begin{tabular}{|c|c|c|c|c|c|c|c|c|c|}
\hline \multirow[b]{2}{*}{ Study } & \multirow[b]{2}{*}{ Year } & \multicolumn{2}{|c|}{ Patients } & \multicolumn{2}{|c|}{ Controls } & \multirow{2}{*}{$\begin{array}{l}\text { Weighted mean difference } \\
\text { (95\% CI fixed) }\end{array}$} & \multirow{2}{*}{$\begin{array}{l}\text { Weight } \\
(\%)\end{array}$} & \multicolumn{2}{|c|}{ Weighted mean difference } \\
\hline & & $n$ & Mean \pm SD & $n$ & Mean \pm SD & & & Mean difference & $(95 \% \mathrm{CI})$ \\
\hline Barton et al. (8) & 1995 & 4 & $464 \pm 135$ & 4 & $386 \pm 65$ & 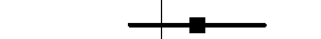 & 4.7 & 78 & $(-69$ to 225$)$ \\
\hline Ackerman et al. (10) & 1998 & 6 & $364 \pm 52$ & 2 & $372 \pm 20$ & - & 40.6 & -8 & $(-58$ to 42$)$ \\
\hline Farrell et al. (11) & 2001 & 10 & $385 \pm 84$ & 7 & $322 \pm 71$ & & 18.5 & 63 & $(-11$ to 137$)$ \\
\hline Present study & 2002 & 6 & $384 \pm 53$ & 5 & $379 \pm 36$ & & 36.1 & 5 & $(-48$ to 58$)$ \\
\hline \multirow[t]{2}{*}{ Pooled data } & - & 26 & 380 & 18 & 366 & & 100 & 14 & $(-18$ to 46$)$ \\
\hline & & & & & & 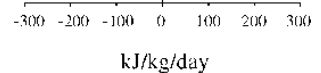 & & & \\
\hline
\end{tabular}

Total daily energy expenditure in $\mathrm{kJ} \mathrm{kg}^{-1} \mathrm{~d}^{-1}$.

95\% CI: $95 \%$ confidence interval.

Test for heterogeneity: $\chi^{2}=3.27, \mathrm{df}=3, p=0.35$; test for overall effect: $z=0.85, p=0.4$. 
percentage TBW was increased compared with the controls $\left(98 \mathrm{~kJ} \mathrm{~kg}^{-1} \mathrm{~d}^{-1}, 95 \%\right.$ CI 80 to $116, p<0.0001$; and $7 \%$ of body weight, $95 \%$ CI 5 to $10, p<0.0001$, respectively) (Table $3 \mathrm{a}, \mathrm{b}$ ). No differences in TDEE were found between CHD infants with versus without CHF (mean difference $14 \mathrm{~kJ} \mathrm{~kg}^{-1} \mathrm{~d}^{-1}, 95 \% \mathrm{CI}-18$ to 46) (Table 3c).

\section{Discussion}

This study shows that mean TDEE is increased in infants with CHD between 2 and 8 mo of age. The result from this study in 11 patients (mean TDEE $+83 \mathrm{~kJ} \mathrm{~kg}^{-1} \mathrm{~d}^{-1}$ compared with healthy controls) and the overall effect of the meta-analysis from 65 patients (mean TDEE $+97 \mathrm{~kJ} \mathrm{~kg}^{-1} \mathrm{~d}^{-1}, \sim 35 \%$ above values in healthy infants of similar age) demonstrate a substantial elevation on the group level. Differences in TBW were also present, but were relatively minor. The consequences and limitations of this study will be discussed.

Previous DLW studies also reported elevated TDEE in infants with CHD, but results varied in effect size and SD. The small numbers of subjects in these studies, and in the present study, impose a limitation on the accuracy of the calculated effect. Pooling of the data from the systematic review of DLW studies and the added value of the meta-analysis largely overcame this limitation. The wider SD for TDEE in some of the previous studies $(8,13,19)$ might be due to greater heterogeneity in diagnosis and pathophysiology between the patients in these studies. In the present study, the coefficient of variation for TDEE in CHD infants was smaller and this may be due to the selection of infants with CHD and a left-to-right shunt.

One should be cautious to conclude that elevated TDEE occurs in all (groups of) CHD patients. Selection bias was present in the present study, as all but one patient had a weight below the median of the Dutch reference population and growth failure was present in five patients. Therefore, the patients in this study, and many of those included in the meta-analysis, on average had a diminished nutritional status compared with the healthy controls. Results for TDEE could be affected by the difference in body weight, which is corrected by expressing TDEE per kilogram body weight.

Changes in body composition could be related to the findings. The CHD infants had an increased percentage of TBW compared with the healthy controls, but the effects in this study $(+8 \%)$ and in the meta-analysis $(+7 \%)$ were moderate. The higher percentage of TBW in CHD might be explained by a relative decrease in fat mass, an increase in the hydration of the fat-free mass, or both. The significantly lower BMI in the CHD infants in this study is compatible with a lower fat mass, but could in theory also be explained by a reduction in other tissues such as skeletal muscle. No independent measurement of fat mass was conducted. Alternatively, it is possible that the hydration of the fat-free mass was increased in CHD patients with a left-to-right shunt, owing to the pooling of blood in the right heart and the lungs, and systemic water retention. Treatment with diuretics could reduce this. If one assumes unchanged hydration of the fat-free mass, the higher proportion of fat-free mass may partly explain the elevated TDEE per unit of body weight, because energy expenditure in fatfree mass is higher than in fat tissue. However, the observed change in TBW is minor and in itself cannot explain the elevated TDEE.

Growth retardation, as frequently observed in infants with CHD, may be multifactorial. In the present study, in a subgroup of patients with CHF and growth retardation, ingested energy was not significantly different from controls (despite the intended higher energy intake), as a result of vomiting. Faecal energy excretion was not abnormal. These results are in accordance with the literature (1). It should be noted that the present study was cross-sectional, and caution should be applied when making inferences about causality. Nevertheless, the very low energy for growth in the subgroup of CHD children with $\mathrm{CHF}$ and growth retardation, and the inverse relationship between TDEE and standardized weight in the CHD study group, indicate that the elevated TDEE in CHD infants at least partly explains the growth retardation in the subgroup. A disturbed metabolism may add to the growth retardation. Lundell et al. found increased insulin secretion in combination with low plasma insulin after an intravenous glucose tolerance test in CHD patients with ventricular septal defects compared with healthy controls. This suggested that increased peripheral binding or extraction of insulin is present in infants with CHD after carbohydrate loading (22). Furthermore, upon intravenous lipid loading, disturbances in plasma free-fatty acid levels have been described in infants with CHD (patients with a ventricular septum defect or transposition of the great arteries) (23). The authors of the latter study commented that the findings could be partly explained by the presence of cyanotic CHD in their study group. Studies relating TDEE and energy available for growth to utilization of macronutrients have not been performed in patients with CHD (either with or without cyanosis). Thus, with present knowledge, it is not possible to explain the metabolic abnormalities in carbohydrate and lipid metabolism from the viewpoint that TDEE is increased in (subgroups of) infants with CHD.

In some patients with CHD and a severe right-to-left shunt, growth failure due to severe hypoxia can be postulated. However, in infants with a cyanotic CHD, Leitch et al. found mean TDEE to be increased by $29 \%$ (13). In infants with CHD (with either a left-to-right or right-to-left shunt) and growth failure, elevated TDEE appears to be present but other factors, either related to the disturbed energy expenditure or not, may also contribute to the growth failure. 
The mean TDEE in CHD patients with CHF in the present study was very similar to that in patients without this clinical condition. Previous studies suggested increased TDEE in CHD infants with CHF compared with those without $\mathrm{CHF}$, but the observed differences were not significant $(8,10,11)$. The results of the metaanalysis showed a minor and non-significant difference between the two conditions. This finding is contrary to the current understanding that in CHD and CHF energy expenditure is elevated owing to increased work of the heart, diminished efficiency of the myocardium, increased work of breathing and more sympathetic stimulation (2). In the present study and the previous studies the patients with CHF were treated with diuretics (and fluid restriction). It is possible that the treatment reduced the haemodynamic abnormalities and fluid overload, and this may confound a possible effect of heart failure on TDEE.

Although other factors need to be taken into account, the substantial overall effect size and limited variance of TDEE in infants with CHD have consequences for the management of preoperative infants with CHD and growth failure. It follows from the distribution curve that only a small proportion of patients will have a TDEE below the median of healthy controls. In the present study, each of the 11 patients had a TDEE above the mean of the reference population, irrespective of the presence of growth failure. Increased energy intake will be necessary in the preponderance of the patients with diminished SDS for weight to compensate for the elevated TDEE, and the feeds should contain enough energy for catch-up and for maintaining TDEE under optimal nutritional status.

Little is known about the cellular and endocrine regulatory mechanisms, the energetic contributions of specific organs and tissues, or the aetiology of vomiting and other factors related to TDEE and growth failure in CHD. Elevated TDEE and low physical growth in infants with CHD are known to normalize soon after successful surgery of the underlying CHD is conducted (8). Early selection of the patients with growth failure for this treatment should be integrated in the intervention strategy and decision making. When infants with CHD and faltering growth do not qualify for early corrective heart surgery, the likelihood that the energy expenditure is increased should be considered in the nutritional management.

Acknowledgements.-Nutricia (Zoetermeer, The Netherlands) provided financial support for this study. We thank Mrs A van MaarenCassé for assistance and patient care, and Dr NC de Bruin and Prof. Dr HKA Visser for providing the data on the control infants.

\section{References}

1. Vaisman N, Leigh T, Voet H, Westerterp K, Abraham M, Duchan R. Malabsorption in infants with congenital heart disease under diuretic treatment. Pediatr Res 1994; 36: 545-9
2. Lees M, Bristow J, Griswold H, Olmsted R. Relative hypermetabolism on infants with congenital heart disease and undernutrition. Pediatrics 1965; 36: 183-91

3. Stocker FP, Wilkoff W, Miettinen OS, Nadas AS. Oxygen consumption in infants with heart disease. Relationship to severity of congestive failure, relative weight, and caloric intake. J Pediatr 1972; 80: 43-51

4. Krauss AN, Auld PA. Metabolic rate of neonates with congenital heart disease. Arch Dis Child 1975; 50: 539-41

5. Huse DM, Feldt RH, Nelson RA, Novak LP. Infants with congenital heart disease. Food intake, body weight, and energy metabolism. Am J Dis Child 1975; 129: 65-9

6. Menon G, Poskitt EM. Why does congenital heart disease cause failure to thrive? Arch Dis Child 1985; 60: 1134-9

7. Jackson M, Poskitt EM. The effects of high-energy feeding on energy balance and growth in infants with congenital heart disease and failure to thrive. Br J Nutr 1991; 65: 131-43

8. Barton JS, Hindmarsh PC, Scrimgeour CM, Rennie MJ, Preece MA. Energy expenditure in congenital heart disease. Arch Dis Child 1994; 70: 5-9

9. Mitchell IM, Davies PS, Day JM, Pollock JC, Jamieson MP. Energy expenditure in children with congenital heart disease, before and after cardiac surgery. J Thorac Cardiovasc Surg 1994; 107: $374-80$

10. Ackerman IL, Karn CA, Denne SC, Ensing GJ, Leitch CA. Total but not resting energy expenditure is increased in infants with ventricular septal defects. Pediatrics 1998; 102: 1172-7

11. Farrell AG, Schamberger MS, Olson IL, Leitch CA. Large leftto-right shunts and congestive heart failure increase total energy expenditure in infants with ventricular septal defect. Am J Cardiol 2001; 87: 1128-31, A10

12. Leitch CA, Karn CA, Ensing GJ, Denne SC. Energy expenditure after surgical repair in children with cyanotic congenital heart disease. J Pediatr 2000; 137: 381-5

13. Leitch CA, Karn CA, Peppard RJ, Granger D, Liechty EA, Ensing GJ, Denne SC. Increased energy expenditure in infants with cyanotic congenital heart disease. J Pediatr 1998; 133: 755-60

14. de Bruin NC, Degenhart HJ, Gal S, Westerterp KR, Stijnen T, Visser HK. Energy utilization and growth in breast-fed and formula-fed infants measured prospectively during the first year of life. Am J Clin Nutr 1998; 67: 885-96

15. Fredriks AM, van Buuren S, Burgmeijer RJF, VerlooveVanhorick SP, Wit JM. Dutch growth diagrams 1997 in historical perspective. In: Wit JM, editor. The fourth national survey on growth. Leiden: Boerhaave Commissie; 1998: 1-14 (in Dutch)

16. Westerterp KR. Body composition, water turnover and energy turnover assessment with labelled water. Proc Nutr Soc 1999; 58: 945-51

17. Weir JB, de V. New methods for calculating metabolic rate with special reference to protein metabolism. J Physiol 1946; 109: 1-9

18. de Meer K, Westerterp KR, Houwen RH, Brouwers HA, Berger $\mathrm{R}$, Okken A. Total energy expenditure in infants with bronchopulmonary dysplasia is associated with respiratory status. Eur $\mathbf{J}$ Pediatr 1997; 156: 299-304

19. Leitch CA, Wright-Coltart SI, Schamberger MS, Farrell AG. Energy expenditure in infants with hypoplastic left heart syndrome. Pediatr Res 2002; 51(4)39A

20. Leitch CA. Growth, nutrition and energy expenditure in pediatric heart failure. Prog Pediatr Care 2000; 11: 195-202

21. Davies PS, Ewing G, Lucas A. Energy expenditure in early infancy. Br J Nutr 1989; 62: 621-9

22. Lundell KH, Sabel KG, Eriksson BO, Mellgren G. Glucose metabolism and insulin secretions in infants with symptomatic ventricular defects. Acta Paediatr 1989; 78: 620-6

23. Lundell KH, Sabel KG, Eriksson BO. Plasma metabolites after a lipid load in infants with congenital heart disease. Acta Paediatr 1999; 88: 718-23

Received July 15, 2002; revisions received Jan. 17, 2003; accepted Mar. 27, 2003 